\title{
鉄筋コンクリートの曲げひび割れ部に生じる腐食の 形成機構に及ぼす水セメント比の影響
}

\author{
大即信明 ${ }^{1}$ - 宮里心 ${ }^{2} \cdot$ 柴田常徳 ${ }^{3}$ - 久田真 ${ }^{4} \cdot T^{2}$ arek Uddin Md. ${ }^{5}$ - 長瀧重義 ${ }^{6}$ \\ ${ }^{1}$ 正会員 工博 東京工業大学教授 工学部開発システムエ学科(テ152-8552目黒区大岡山2-12-1) \\ ${ }^{2}$ 正会員 工修 東京工業大学助手 工学部開発システム工学科 \\ ${ }^{3}$ 正会員 工修 大林組株式会社(干592-0001大阪府高石市高砂3-1) \\ ${ }^{4}$ 正会員 工博 新渴大学助教授工学部建設学科( ( $950-1401$ 新渴市五十嵐二の町 8050 ) \\ ${ }^{5}$ 正会員 工博 株式会社ニュージェック（テ542-0082大阪市中央区島之内1-20-19） \\ ${ }^{6}$ 工吅-会員 工博 新渴大学教授 工学部建設学科
}

\begin{abstract}
水セメント比の相違が，鉄筋コンクリートの曲げひび割れ部に形成される腐食の形成機構に及ぼす影響 を，実験的に検討した．初めに，モルタルを用いた腐食促進試験を行い，塩化物イオン浸透性および酸素 透過性と腐食形態の関連を調べた。ここで用いた供試体は，実構造物では測定不可能な鉄筋内部を流れる 電流を測定するため，7本に分割した鉄筋をモルタル内部に埋設した。さらに，曲げひび割れ近傍に生し る，鉄筋とモルタルの剥離部を考虑した．最後に，鉄筋コンクリート梁供試体を用いた腐食試験により， モルタル試験を検証した．この結果，鉄筋コンクリートの曲げひび割れ部に生しる，腐食の発生機構とそ の後の進行形態が明らかとなった。
\end{abstract}

Key Words:chloride induced corrosion, bending crack, macrocell corrosion, microcell corrosion, W/C

\section{1.はじめに}

コンクリートは現代の社会基盤を形成してきた 最も重要な材料の一つであり, 今後もその利用が 期待される。しかしながら，これまでに建設され た鉄筋コンクリート構造物の一部に対し，塩害に よる早期の劣化が指摘され，その耐久性がクロー ズアップされてきた。

一般に，鉄筋コンクリート構造物は，かぶりに より, 腐食要因となる塩化物イオン, 酸素および 水分の浸透を抑制している.しかしながら，コン クリートにひび割れが存在すると, それらの物質 を鉄筋まで容易に浸透させ，比較的早期に腐食が 発生する.特に,ひび割れ部においてマクロセル 腐食が発生すると, さらに腐食は促進し, 早期劣 化を引き起こすこととなる.

ひび割れ部に形成するマクロセル腐食に関する

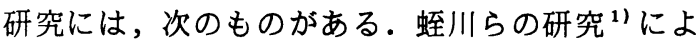
れば，腐食形態は全般に局部腐食型であり，ひび
割れ面と交わる付近で, 最も著しい腐食が発生す るとしている. 宮川らの研究 ${ }^{21,3) に よ れ は ゙, ~ マ ~}$ クロセル腐食は, ひび割れ籄所と部材内部の鉄筋 の電位差が起電力になり生じる.ひび割れの存在 は腐食を局部化するが, 腐食領域はひび割れ部の みならず近傍を含んだ領域である．また，大野，

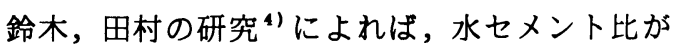
$50 \%$ と $70 \%$ の場合は, ひび割れの有無が腐食に大 きく影響を及ぼす。一方，30\%では，鉄筋の腐食 開始は著しく遅く腐食量も小さいとしている. 筆 者ら ${ }^{5)}$ は, ひび割れと交わる部分の鉄筋は, 乾湿 の条件によってはマクロセルにおけるアノードま たはカソードと変化することを指摘した。しかし ながら，いずれの研究においても，マクロセル腐 食について，アノードとカソードの位置関係を特 定せずに考察しているのが現状である.

以上のことから, 本研究では, 鉄筋コンクリー トの曲げひび割れ部に生じる腐食の発生機構およ びその後の進行形態の解明を目的として, 水セメ 
表-1 セメントの物理的性質および化学成分

\begin{tabular}{|c|c|c|c|c|}
\hline \multirow{11}{*}{ 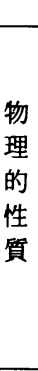 } & & & 王l外 & ヨンクリリ-卜 \\
\hline & 密度 & $\mathrm{g} / \mathrm{cm}^{3}$ & 3.15 & 3.15 \\
\hline & ブレー比表面積 & $\mathrm{cm}^{2} / \mathrm{g}$ & 3260 & 3080 \\
\hline & 凝結：水量 & $\%$ & 28.3 & 27.2 \\
\hline & 始発 & 時一分 & $2-22$ & $2-28$ \\
\hline & 終結 & 時一分 & $3-55$ & $3-20$ \\
\hline & 安定性（竟沸方法 & & 良 & 良 \\
\hline & フロー値 & & 240 & 240 \\
\hline & 王縮強さ： & $\mathrm{MPa}$ & 16.6 & 16.0 \\
\hline & 7 日 & $\mathrm{MPa}$ & 26.7 & 27.5 \\
\hline & 28 日 & $\mathrm{MPa}$ & 42.7 & 42.5 \\
\hline 化 & 強熱減量 & $\%$ & 1.4 & 0.6 \\
\hline 学 & 不溶残分 & $\%$ & 0.62 & 0.65 \\
\hline 成 & $\mathrm{MgO}$ & $\%$ & 1.5 & 2.0 \\
\hline 分 & $\mathrm{SO}_{3}$ & $\%$ & 1.9 & 1.9 \\
\hline & $\mathrm{C} \mathrm{I}^{-}$ & $\%$ & 0.005 & 0.01 \\
\hline
\end{tabular}

ント比に相遠を設け，実験的検討を行った。すな わち，曲げひび割れ近傍に生じる鉄筋とコンクリ 一トの剥離部(肌離れ) のにおける塩化物イオン 浸透性, およひひび割れ箇所と部材中の酸素透過 性の比較を詳細に検討し, 経時的に変化するマク ロセルにおけるアノードとカソードの位置関係お よびミクロセル腐食の発生箇所を特定した.

本論文の構成および使用した供試体の特徴を記 す．まず初めに，モルタル供試体を用い，塩化物 イオン浸透性および酸素透過性と, 腐食形態の関 連を暴露期間毎に検討した。ここでは，水セメン 卜比を 3 通り $(30,50,70 \%)$ 設定し比較検討した. 使用した供試体は，鋼材内部を流れる電流を測定 可能とするため, 7 本の要素に分割した鉄筋を埋 設した。また， 3 点曲げ載荷によりひひ割れを作 製することにより，曲げひび割れ近傍に生じる鉄 筋とコンクリートの剥離部を考虑することを可能 とした．最後に，鉄筋コンクリート梁供試体を用 いた試験により，モルタル試験を検証した。

\section{2. 实験概要}

\section{（1）使用材料}

セメントは，表-1に示す物理的性質および化学 成分の普通ポルトランドセメントを使用した。

骨材は，表-2に示す物理的性質の千葉県小檟産 の細骨材 (山砂) および東京都青梅産の粗骨材 （砕石）を使用した。

混和剂は，ブリーディングを防止するため，水 セメント比が70\%のモルタルにおいて，メチルセ ルロース系水中不分離性混和剤を水質量に対して, $1.2 \%$ 添加した.また, 水セメント比が $30 \%$ のモ
表-2 骨材の物理的性質

\begin{tabular}{|c|c|c|c|c|}
\hline & 最大寸法 & 粗粒率 & 表乾比重 & 吸水率 \\
\hline \hline 細骨材 & $5 \mathrm{~mm}$ & 2.20 & 2.62 & $1.17 \%$ \\
粗骨材 & $20 \mathrm{~mm}$ & 6.65 & 2.64 & $0.81 \%$ \\
\hline
\end{tabular}

表-3 鋼材の化学成分

\begin{tabular}{|c|c|c|c|c|c|}
\hline $\mathrm{Fe}$ & $\mathrm{C}$ & $\mathrm{S} \mathrm{i}$ & $\mathrm{Mn}$ & $\mathrm{P}$ & $\mathrm{S}$ \\
\hline \hline 99.1 & 0.12 & 0.12 & 0.58 & 0.031 & 0.023 \\
\hline
\end{tabular}

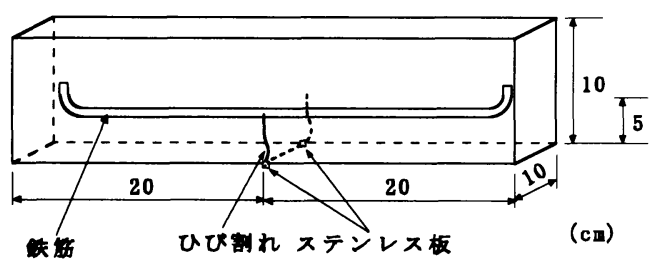

（a）モタル(1)供試体

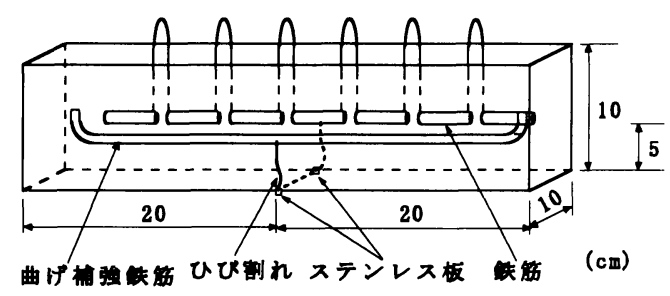

(b)モルタル(2供試体

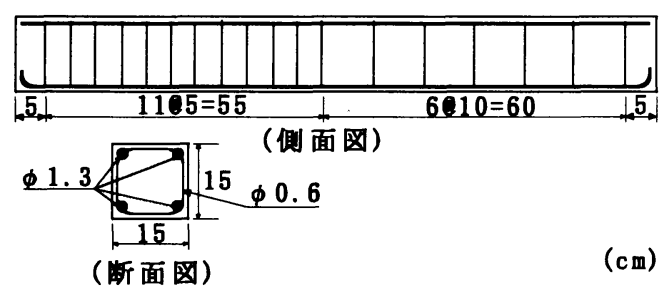

(c)コンクリート供試体

図-1 供試体概要図

ルタルにおいて，ナフタレン系高性能 $\mathrm{A} E$ 減水剂 をセメント質量に対して， 2 \%添加した。一方， コンクリートにおいては, スランプおよび空気量 が一定となる様に，スルホン酸系 $\mathrm{AE}$ 減水剂およ び A E 助剤を添加した。なお,これらの混和剤が 腐食に及ほす影響は少ないと思われる。

鋼材は，表-3に示す化学成分の丸鋼を使用した。

\section{（2）供試体の作製方法}

本研究で使用した供試体を，図-1に示す．モル タル(1)供試体を用いて，塩化物イオン浸透分布お よびモルタルと鉄筋の剥離面積を測定した。モル 


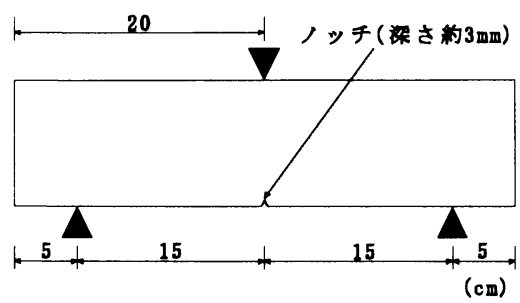

（a モルタル (1)・ (2)供試体

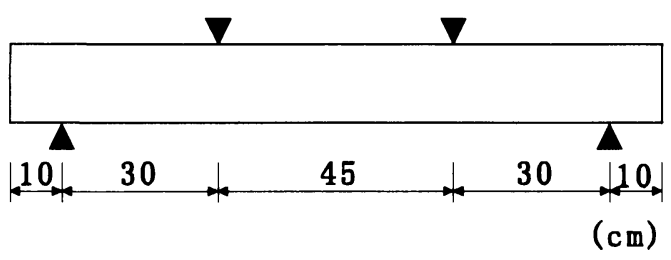

（b）コンクリート供試体

図-2＼cjkstart曲げひび割れ作製方法

タル2供試体を用いて,ひび割れ部における酸素 透過量，あるいは鉄筋の腐食程度を評価した。

a ）モルタル(1)供試体

使用した鉄筋は，クエン酸二水素アンモニウム に24時間浸漬させた後, ワイヤブラシにより黒皮 を剥いだ。打設後，相対湿度 $80 \%$ 室温 20 度にて湿 空養生を行った。材齢28日目において，供試体下 面の中央部に曲げひび割れを設けた．曲げひび割 れは，図-2に示すように，予め供試体下面に深さ が約3mmのノッチを設け，3点曲げ載荷により生 じさせた。マイクロスコープを用いひび割れ開口 部を観察し，ひび割れ幅が0.3mmに達した時点で 載荷を終了し, 厚さが $0.1 \mathrm{~mm}$, 幅が $5 \mathrm{~mm}$ のステンレ ス板をひび割れ開口端部に挟み，曲げひび割れ幅 を0.3mmに制御した（図-1（a ）参照）.また， ひび割れ開口面を除く 5 面を，エポキシ系樹脂に より被覆し，塩化物イオンが 1 面のみから浸透す るようにした。その後, 塩水噴霧 $(\mathrm{NaCl} 3.1 \mathrm{wt} \%)$ を伴う 24 時間の湿潤（相対湿度 $90 \%$ ）と60時間の 乾燥（相対湿度 $50 \%$ ）が絽り返される腐食促進環 境下に暴露した。なお，腐食反応を促進させるた め, 室温は60度とした。

b ) モルタル(2)供試体

供試体内部に埋設した鉄筋を，図一3に示す．使 用した鉄筋は，実構造物では測定不可能な，鉄筋 内部を流れる電流を測定するため，7本に分割し た。各鉄筋は，モルタル(1)供試体と同様に黒皮を 剥き, 鉄筋側面の両側端部にリード線をはんだ付 けした後, 接合部をエポキシ系樹脂により被覆し た。さらにリード線が付いた面を同一方向に揃え，

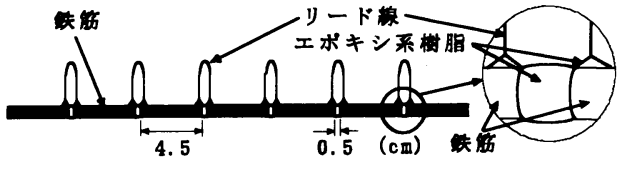

図-3モルタル(2供試体に埋設した内部鉄筋

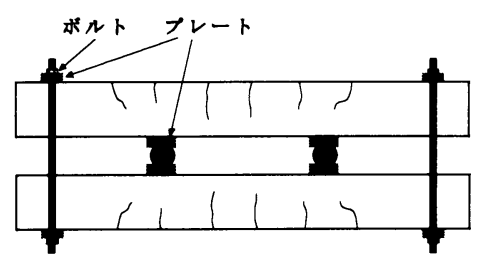

図-4 コンクリート供試体の治具取り付け状況

表-4 コンクリートの配合とフレッシュ性状

\begin{tabular}{|c|c|c|c|c|c|c|c|c|c|}
\hline$w / C$ & s/a & & & & 立重 & & & & Air \\
\hline$(x)$ & (y) & & $(\mathrm{kg}$ & & & 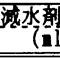 & 县剂 & (c) & $(\boldsymbol{q})$ \\
\hline 50 & 45 & 165 & 330 & 803 & 989 & 743 & 13.2 & 9.0 & 4.9 \\
\hline 70 & 45 & 165 & 236 & 837 & 1032 & 637 & 9.4 & 9.5 & 5.2 \\
\hline
\end{tabular}

エポキシ系樹脂によって鉄筋要素間を接続し，隣 接するリード線を慗いで電気的には 1 体とみなせ る鉄筋とした．前処理が終了した鉄筋は，曲げ載 荷時にリード線の付いた面が圧縮側となるよう， リード線の付いた面を上側にして型枠に設置した。 さらに, 酸素透過性を測定するため, 一部の供試 体に対しては，型枠下面にチタンメッシュを配置 し，打設した．なお，全面にエポキシ系樹脂を被 覆した曲げ補強鉄筋を, 分割鉄筋と並列に埋設し た. 打設後の処理は，モルタル(1)供試体と同様で ある・

c ）コンクリート供試体

鉄筋はワイヤブラシで黒皮を剥いだ後, 引張側 主鉄筋となる鋼材端部にリード線をはんだ付けし， 接合部をエポキシ系樹脂により被覆した。初期養 生方法は，モルタル供試体と同様である。曲げひ び割れは，図-2に示す位置を支点および載荷点と する 4 点曲げ載荷により作製した。ひび割れは, 図-4に示す治具により制御し, 東京工業大学構内

（東京都目黒区）にて1996年8月から屋外暴露を 行った. 1 週間に一度, コンクリート表面に対し て $2.42 \mathrm{~kg} / \mathrm{m}^{2}$ の塩水（ $\left.\mathrm{NaCl} 3.5 \mathrm{wt} \%\right)$ を噴霧した。

\section{（3）実験ケース}

モルタルの配合は，水セメント比が $30 \%, 50 \%$, $70 \%$ の 3 通りとした.いずれの水セメント比にお いても，S/Cは2.5とした。一方，コンクリートの 配合, スランプおよび空気量の測定結果を, 表- 


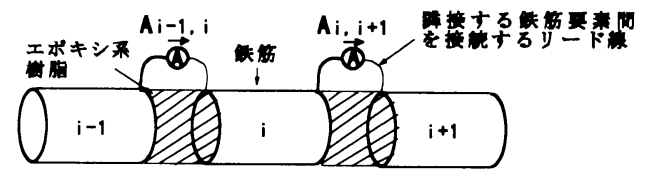

図-5 マクロセル電流密度の測定方法

4に示す.

\section{（4）測定項目と測定方法}

本研究では, 異なる鉄筋要素間を流れる電流か ら推定した腐食電流密度を, マクロセル電流密度 と呼ぶ.すなわち，マクロセルとは，アノードと カソードが異なる鉄筋要素に跨り形成する腐食セ ル（回路）と定義する。一方，一時的にリード線 を切断し，異なる鉄筋間では電流が流れない状態 で測定した分極抵抗を用い推定した腐食電流密度 を, ミクロセル電流密度と呼ぶ.すなわち, ミク ロセルとは，アノードとカソードが単一の鉄筋要 素内に存在する腐食セル（回路）と定義する.し たがって, マクロセル電流とミクロセル電流を合 計することにより，全腐食電流が求まる.

\section{a )自然電位の測定}

照合電極に飽和硫酸銅電極を用い, 自然電位を 測定した。モルタル試験においては，鉄筋要素間 を接続するリード線を一度切断し，切断による電 位の変化が収束した後, 測定した。

\section{b )マクロセル電流密度の測定}

隣接する鉄筋要素間に無抵抗電流計を接続し電 流(マクロセル電流)を求めた.そして, 対象とす る鉄筋要素の両端から出入する電流を合計し, 鉄 筋要素の表面積で除することにより，鉄筋要素表 面でのマクロセル電流密度を算定した．例えば， 図-5に示す鉄筋要素 $i$ のマクロセル電流密度

$\left(a_{i}\right)$ は, 次式で表せる.

$$
a_{i}=\frac{A_{i-1, i}-A_{i, i+1}}{S_{i}}
$$

ここで, $S_{i}=$ 鉄筋要素 $i$ の表面積

そして, 対象とする鉄筋要素表面にてモルタル 中に流出するアノード電流密度は正, モルタル中 から流入するカソード電流密度は負として表した. なお, 腐食電流密度が $100 \mu \mathrm{A} / \mathrm{cm}^{2}$ は, 腐食速度が $1.16 \mathrm{~mm} /$ 年に相当する ${ }^{7)}$.

c ) ミクロセル電流密度の測定

鉄筋要素間を接続するリード線を一度切断し， 異なる鉄筋要素間では電流の出入が無い状態にし，

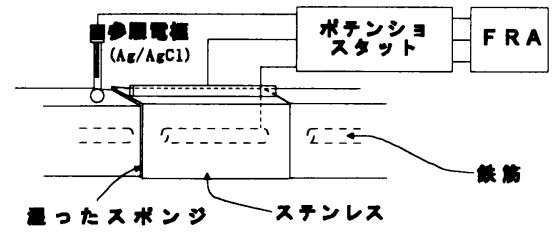

图-6 分極抵抗の測定方法

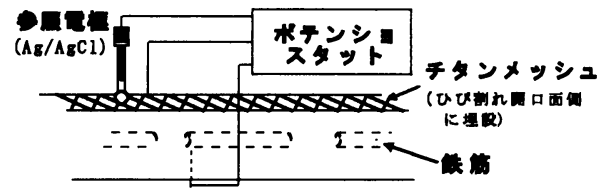

図-7 酸素透過量の測定方法

各鉄筋要素毎の鉄筋表面の分極抵抗を周波数応答 解析装置を用いた交流インピーダンス法により求 めた。概略図を図-6に示す．測定は，5000Hzから $0.0005 \mathrm{~Hz}$ の範囲において, 振幅 $50 \mathrm{mV}$ 電圧を与え ることにより行った。また，分極抵抗は，ボード 線図およびコールコールプロットを用い算定した. そして, 次式を用いて鉄筋要素iのミクロセル電 流密度 $\left(\mathrm{b}_{i}\right)$ を算定した ${ }^{8)}$.

$$
b_{i}=\frac{K}{R p_{i} \times S_{i}}
$$

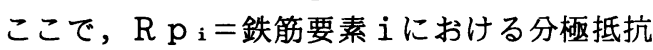

なお，Kは定数であるが本研究では，文献 8 ) を参考にし，0.0209(V)とした。

\section{d)酸素透過量の測定}

図-7に，酸素透過量の測定の概略図を示す．測 定方法は, 鉄筋とチタンメッシュ間にポテンショ スタットを接続し, 鉄筋を陰極, チタンメッシュ を陽極として，860 mVの電位差を設けた。この電 位差は，予め同様の供試体においてカソード分極 曲線を求め, 限界電流密度となる電位であり，し かも水素発生がないことを確認した。この值は， 文献 9 ）および10）と同様な值である. 定常状態 における電流を測定し，鉄筋表面でのカソード反 応において消費された酸素量を次式から算定した.

$$
\frac{d Q}{d t}=-\frac{i_{1 i m}}{n F}
$$

ここで,

$\frac{\mathrm{d} Q}{\mathrm{~d} t}=$ 単位時間当たりの酸素透過量 $(\mathrm{mol} / \mathrm{s})$

$i_{1 \mathrm{im}}=$ 限界電流密度 $\left(\mathrm{A} / \mathrm{cm}^{2}\right)$

$$
\begin{aligned}
& \mathrm{n}=4 \\
& \mathrm{~F}=\text { ファラデー定数 }(=96500 \mathrm{c} / \mathrm{mol})
\end{aligned}
$$




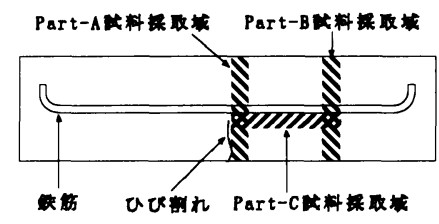

図-8 可溶性塩化物イオン含有量試験の試料採取域

\section{e )腐食減量の測定}

供試体から取り出した鉄筋を，10\%クエン酸二 水素アンモニウム水溶液に24時間浸漬させて錆を 溶解した. その後，サンドペーパおよびワイヤブ ラシを用い表面の付着物を完全に除去し，鉄筋の 質量を測定し，打設前の鉄筋との質量差から，腐 食減量を算定した。さらに，鉄筋要素の長さで除 することにより，鉄筋単位長さ当たりの腐食減量 を求めた。

\section{f）可溶性塩化物イオン含有量の測定}

ダイヤモンドカッターにより，図-8に示す，対 象とする部材を切り取った.Part-Aはひび割れ近 傍, Part-Bはひび割れの影響を受けないモルタル 内部，Part-Cは鉄筋下面近傍である。採取した試 料は質量を測定し，105度の乾燥炉にて24時間乾 燥させた。その後, 乾燥した試料の質量を測定し, 次式より，含水率を算定した。

$$
\begin{aligned}
& \mathrm{C}_{\mathrm{w}}= \frac{\mathrm{W}_{0}-\mathrm{W}_{1}}{\mathrm{~W}_{1}} \times 100 \\
& \text { ここで, } \mathrm{C}_{\mathrm{w}}: \text { 試料の含水率 }(\mathrm{wt} \%) \\
& \mathrm{W}_{0}: \text { 乾燥前の試料質量 }(\mathrm{g}) \\
& \mathrm{W}_{1}: \text { 乾燥後の試料質量 }(\mathrm{g})
\end{aligned}
$$

乾燥させた試料は, $105 \mu \mathrm{m}$ 以下の大きさに粉 砕した。この試料 $10 \mathrm{~g}$ を $100 \mathrm{~g}$ の蒸留水に浸漬さ せ，50度の恒温室に24時間保存し，その後室温が 20 度の環境中にて, 水溶液の温度が 20 度になるま で保存した。この溶液中の塩分量を，塩分濃度計 を用いて測定し，次式から，モルタルの単位質量 当たりの可溶性塩化物イオン量を算定した.

$$
\mathrm{C}_{\mathrm{c} 1}=\frac{\mathrm{C}_{\mathrm{m}}}{10} \times \frac{100}{100+\mathrm{C}_{\mathrm{w}}}
$$

ここで,

$\mathrm{C}_{\mathrm{c}_{1}}$ : モルタルの単位質量当たりの可溶性塩化 物イオン量 $(w t \%)$

$\mathrm{C}_{\mathrm{m}}$ : 測定された可溶性塩化物イオン量(\%)

g ）モルタルと鉄筋の剥離（肌離れ）面積の測定 ひび割れ開口部から，1\%フェノールフタレイ
ンアルコール水溶液を注入し，ひび割れ部および 曲げひび割れ近傍に生じたモルタルと鉄筋の剥離 部へ浸透させた。十分に乾燥させた後，供試体を 割裂し, 鉄筋とモルタルの付着面における変色面 積を測定し, 剥離面積とした。

\section{3．モルタル供畇体を用いた庽食促進試験}

\section{（1）実験結果-1(水セメント比と腐食の関係)}

水セメント比の相違が, 自然電位, マクロセル 電流密度およびミクロセル電流密度に及ほす影響 を図-9〜12に示す．ひび割れ幅は0.3mm，モル夕 ルの水セメント比は $30 \% ， 50 \% ， 70 \%$ である.図 -9は暴露期間が 1 週, 図-10は 2 週, 図-11は 4 週, 図-12は13週の測定結果である。

これによると，自然電位に関しては，暴露期間 が 1 週および 2 週の場合は, いずれの水セメント 比においても，ひび割れ箇所のみが杽になること が認められる.一方, 暴露期間が13週になると， 水セメント比が50\%および70\%の場合は，ひび割 れ近傍の鉄筋も，卑になることが認められる。 マ クロセル電流密度に関しては, 暴露期間が 1 週お よび 2 週においては，ひび割れ箇所でアノード電 流が認められる. 一方, 暴露期間が13週において は，水セメント比が50\%および70\%の場合は，ひ び割れ近傍でアノード電流が認められる.また， ひび割れ箇所のアノード電流は, 暴露期間が 4 週 の場合と比較して, 減少することが認められる. ミクロセル電流密度に関しては, 暴露期間が 1 週, 2 週および 4 週において，ひび割れ箇所で大きく なることが認められる. その值は, 水セメント比 が大きいほど, 増加する. 一方, 暴露期間が 13 週 においては，水セメント比が50\%の場合は，ひび 割れ近傍の鉄筋 (鉄筋の位置= $25 \mathrm{~cm}$ )でも，大きく なることが認められる.水セメント比が $70 \%$ の場 合は，ひび割れからさらに離れた(鉄筋の位置=3 $0 \mathrm{~cm})$ 鉄筋要素でも，大きくなることが認められる. また, 水セメント比が $30 \%$ の場合は, ひび割れ箇 所でのみ, 小さなミクロセル電流が確認できる.

図-13に，腐食電流の和の継時変化を示す．こ こで腐食電流の和とは, 測定されたマクロセル電 流のアノード側の值およびミクロセル電流の值 (図-9〜図-12中の正の電流密度とその鉄筋要素 の表面積を掛けた值）を各々足し会わせたもので ある.これによると，暴露期間に関わらず，水セ メント比が大きいほど, マクロセル電流の和およ びミクロセル電流の和は, 増加することが認めら 


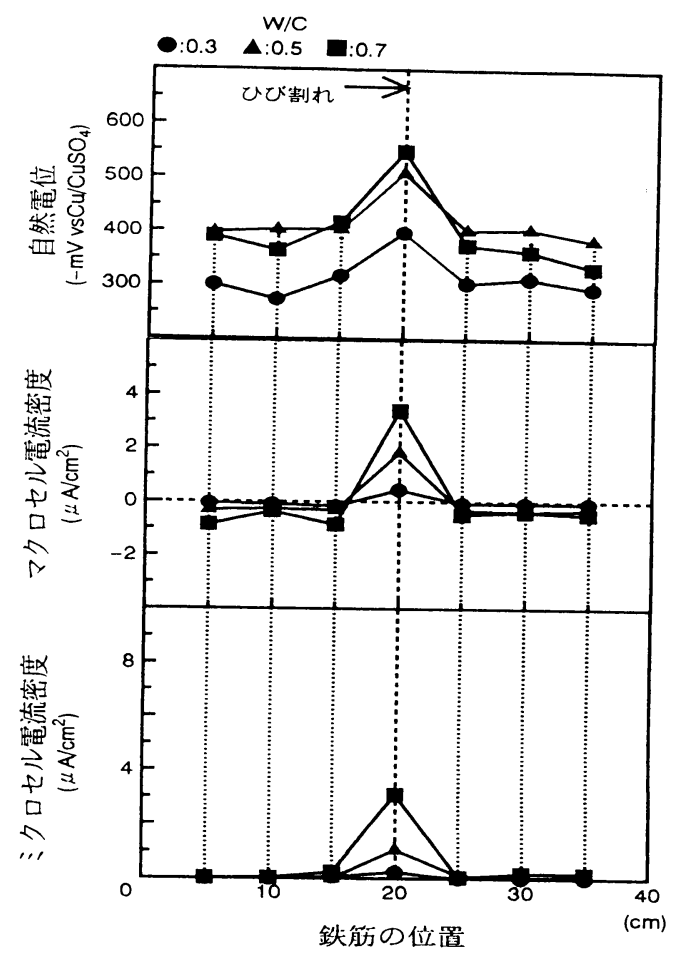

図-9 水セメント比の相違が腐食に及はすす影響 (暴露期間 1 週)

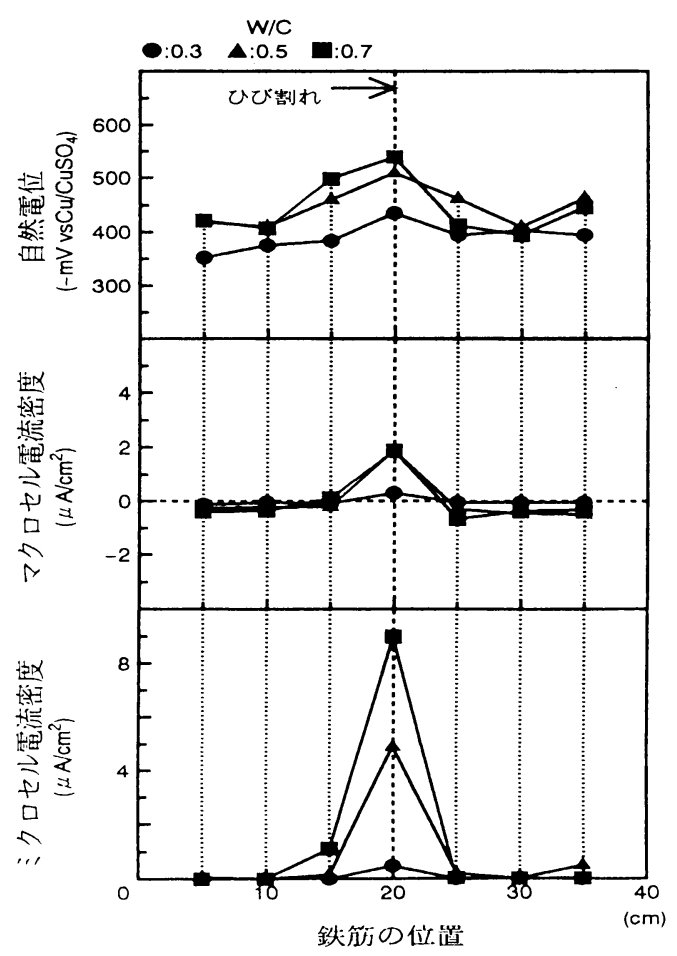

図-11水セメント比の相違が腐食に及ぼす影響 (暴露期間 4 週)

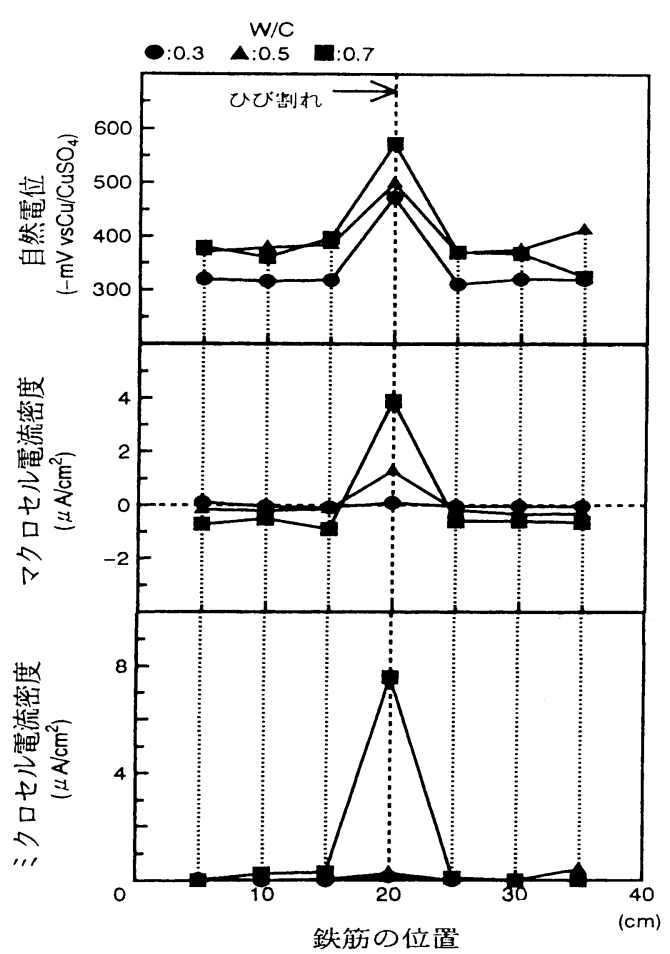

図-10 水セメント比の相違が腐食に及ぼす影響 (暴露期間 2 週)

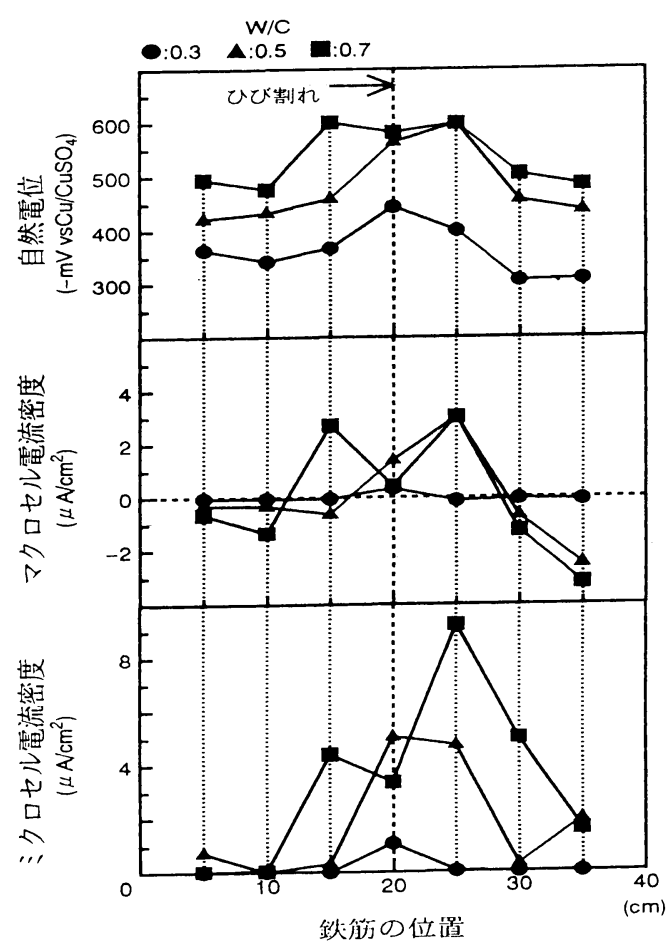

図-12 水セメント比の相違が腐食に及ぼす影響 (暴露期間 13 週) 


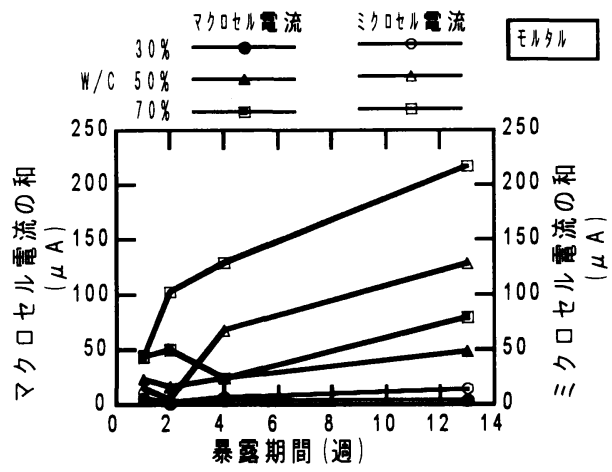

図-13 水セメント比の相違が腐食電量に及ぼす影響

W/C

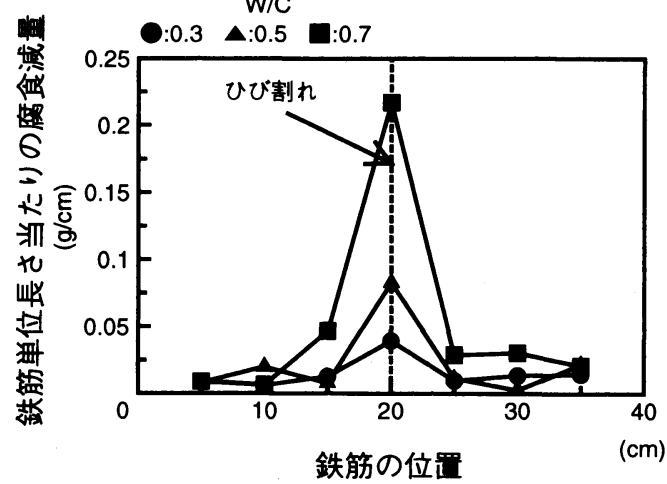

図-14 水セメント比の相違が腐食娍量に及ほす影䇺

れる.また，ミクロセル電流は，マクロセル電流 と比較して，大きいことが分かる。

以上のことから，実験結果をまとめると，次の ことが分かる. マクロセルを形成するアノードと カソードの位置関係に関しては, 暴露期間が短期 の場合は，ひび割れ箇所のみがアノードとなる。 一方, 暴露期間が長期になると, 水セメント比が $50 \%$ おび70\%の場合は，ひび割れ近傍のモルタ ル内部の鉄筋がアノードとなる．ミクロセル電流 の発生箇所に関しても，同様の傾向が見られた。 すなわち, 暴露期間が短期の場合は, ひび割れ䇢 所のみで，ミクロセル腐食の発生が見られた。一 方, 暴露期間が長期になると, 水セメント比が5 0\%および70\%の場合は, ひび割れ近傍のモル夕 ル内部の鉄筋においても, 腐食の進行が確認され た. 特に, 水セメント比が70\%では,ひび割れか ら離れた鉄筋においても，腐食は発生した。また， 腐食速度に関しては, マクロセル腐食速度および ミクロセル腐食速度ともに, 水セメント比が大き いほど増大する．さらに，ミクロセル腐食速度は， マクロセル腐食速度と比較して大きい。

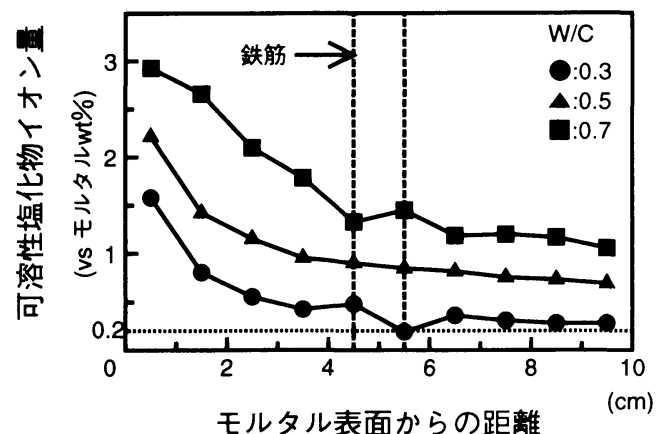

図-15暴蕗期間13週におけるPart-AのCl- 量

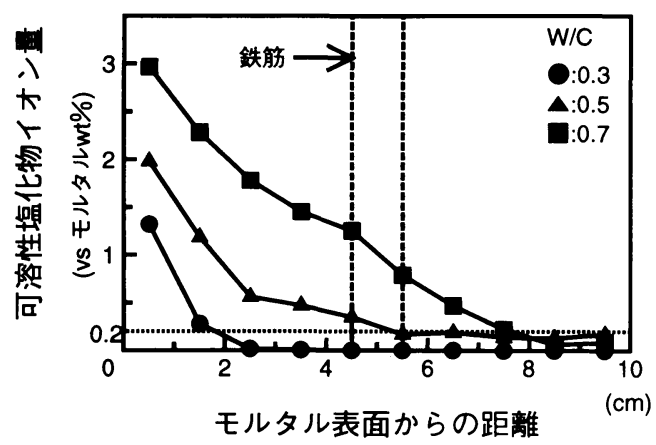

図-16 暴露期間13週におけるPart-BのCl- 量

図-14に，暴露期間が13週における，水セメン 卜比の相違が腐食減量に及ほす影響を示す。これ によると，ひび割れと交わる部分の鉄筋が最も大 きく, その值は水セメント比が大きいほど, 増加 することが認められる.また，水セメント比が7 0\%の場合は，ひび割れ近傍の部材内部の鉄筋に おいても，腐食隇量が大きくなることが分かる。 したがって, 自然電位, マクロセル電流密度およ びミクロセル電流密度から想定される腐食程度と, 内部鉄筋をはつりとり測定した腐食隇量は, 同様 な傾向を示すことが確認できた。

\section{（2）実験結果-2(水セメント比と物質透過性の 阙係)}

図-15〜18に，水セメント比の相違が塩化物イ オン浸透量に及ほす影響を示す.図-15は暴露期 間が13週におけるひび割れ近傍のモルタル中に含 まれる塩化物イオン量分布，図-16は暴露期間が 13週におけるひひ割れから離れたモルタル中に含 まれる塩化物イオン量分布, 図-17は暴露期間が 4 週におけるひび割れからモルタル内部方向への 


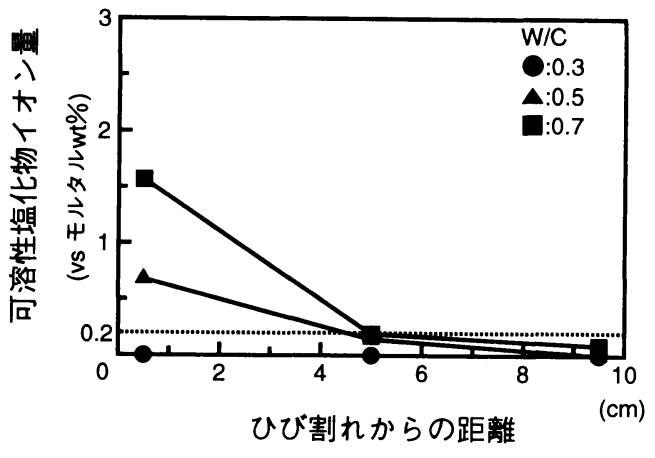

図-17 暴薜期間4週におけるPart-CのCl-量

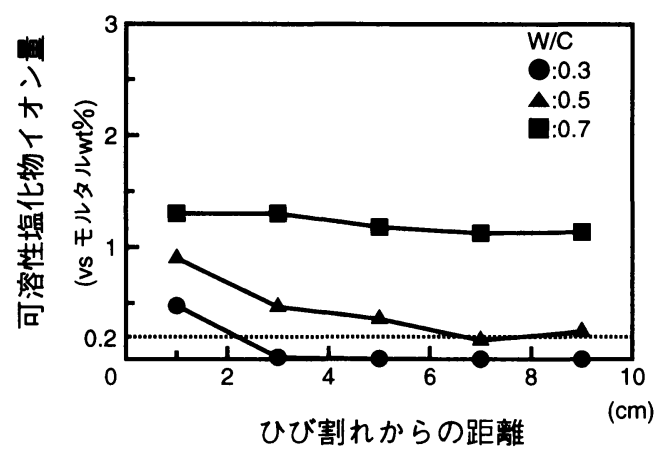

図-18 暴䈃期間13週におけるPart-CのCl- 量

鉄筋下面近傍のモルタルに含まれる塩化物イオン 量分布, 図-18は暴露期間が13週におけるひび割 れからモルタル内部方向への鉄筋下面近傍のモル タルに含まれる塩化物イオン量分布を示す．なお， 図中の点線（可溶性塩化物イオン量 $=0.2 \%$ ）以 上であれば， $50 \%$ 以上の確率で健全な不働態は存 在しない"1)。

図-15によると，ひび割れを通じて浸透する塩 化物イオン量は, 水セメント比が大きいほど増加 することが認められる.同様に，図-16によると， ひび割れの影響が少ないモルタル中を通じて浸透 する塩化物イオン量も，水セメント比が大きいほ ど増加することが認められる"1．次に，図-17と図 -18を比較する。暴露期間が 4 週においては, ひ び割れ箇所のみが多量の塩化物イオンを含有して いることが分かる。一方, 暴露期間が 13 週におい ては，水セメント比が50\%および70\%の場合は， モルタル内部においても，塩化物イオン含有量が 多くなることが認められる.特に, 水セメント比 が70\%の場合は, $50 \%$ の場合と比較して, 暴露期

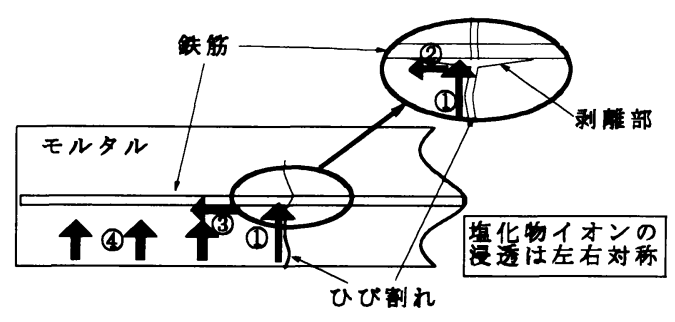

図-19 塭化物イオンの浸透経路

表-5 ひび割れ近傍の鉄筋とモルタルの剥離面積

\begin{tabular}{|c|c|}
\hline $\mathrm{W} / \mathrm{C}$ & 剥醀面積 $\left(\mathrm{cm}^{2}\right)$ \\
\hline 0.3 & 1.53 \\
\hline 0.5 & 2.11 \\
\hline 0.7 & 2.48 \\
\hline
\end{tabular}

間が 4 週の時と比較した塩化物イオン含有量の増 加が多いことが分かる．このことについて，図19を用いて考察する. 塩化物イオンは，かぶりコ ンクリート中を浸透することと比較して，ひび割 れを通じることにより，内部鉄筋に容易に浸透す ることが出来る(1)）、ひび割れを通じての塩化 物イオン浸透量は, 図-15に示す通り, 水セメン 卜比が大きいほど増加する。ひび割れを通じて， 外部環境から内部鉄筋に到達した塩化物イオンの 一部は, 表面からさらに遠いひび割れ内部に浸透 する．他方は，ひび割れ近傍の鉄筋とモルタルの 剥離部に浸透する（2）. 表-5に示す通り，水セ メント比が大きいほど，ひび割れ近傍の鉄筋とモ ルタルの剥離面積が増加する.したがって, 水セ メント比が大きいほど, 剥離部を浸透する塩化物 イオン量は増加すると考えられる．さらに，剥離 部先端に到達した塩化物イオンは, 締固め時に浮 上した空気泡等が貯まり多孔質となった，鉄筋下 面近傍のモルタルを伝わり，健全なモルタル中に 浸透する（3）．以上のことより，外部環境から ひび割れを通じて鉄筋表面に到達し，さらに鉄筋 に沿ってモルタル内部に浸透する塩化物イオンは, 水セメント比が大きいほど, 増加すると考えられ る.さらに, 図-16に示す通り，水セメント比が $70 \%$ では，外部環境からモルタル中を通じて鉄筋 表面に浸透する塩化物イオンも，多量に存在する ことが確認できる（4)）.なお，図-18によれば， 水セメント比が30\%の場合は，13週間暴露した後 においても，モルタル内部へは塩化物イオンが浸 透していないことが認められる.

表-6に, 水セメント比と酸素透過量の関係を示 す.（a )は暴露期間が 4 週，（b ) は13週の測定結 果である. また，各々ひび割れと交わる部分の鉄 筋への酸素透過量, およびモルタル内部の鉄筋へ 
表-7 水セメント比が腐食形成機構に及ぼす影響

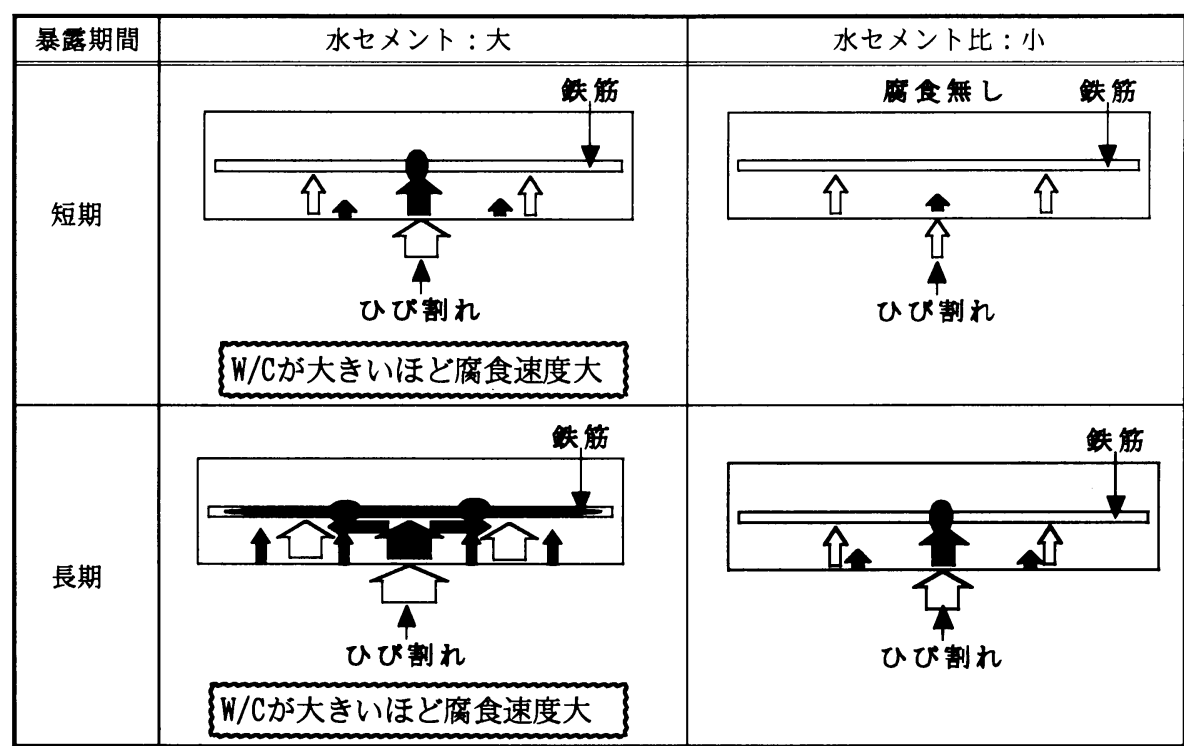

○埴化物イオン浸透（太いほと多い）

既来透過（太いほど多い）

マクロセルのアノード部

○クロセルの席食匴所

の酸素透過量を測定した。（a）によると，暴露期 間が 4 週では，ひび割れと交わる部分の鉄筋にお いて, 水セメント比が大きいほど, 酸素透過量が 増大することが確認できる。一方，（b ）によると， 暴露期間が13週では, 水セメント比が50\%および $70 \%$ の場合，ひび割れを通じての酸素透過量は， 同様に多いことが認められる．また，モルタルを 通じての酸素透過量は, 水セメント比が大きいほ ど, 増大する.この時, ひび割れを通じての酸素 透過量は，モルタル中の酸素透過量と比較して， 多いことが認められる。

\section{( 3 ) 考察}

表-7に，物質透過性と腐食の関連性を整理する。

暴露期間が短期では, 水セメント比が大きい場 合，ひび割れ䇢所において腐食が発生する。これ は，ひび割れと交わる部分の鉄筋のみに塩化物イ オンが浸透するためと考えられる.この時, 水セ メント比が大きいほど，ひび割れ箇所における， 酸素透過量が增大するため, 腐食反応を促進させ る.

一方, 暴露期間が長期では, 水セメント比が $70 \%$ るいは $50 \%$ の場合は, マクロセルのアノー ド部と, ミクロセル腐食の発生箇所に相違が見ら
表-6 水セメント比が酸素透過量に及ぼす影響

\begin{tabular}{|c|c|c|}
\hline \multirow[t]{2}{*}{$\mathrm{W} / \mathrm{C}$} & 酸素透過量 & $\mathrm{mol} / \mathrm{cm}^{2} \mathrm{sec}$ ) \\
\hline & ひび割れ筒所 & 现外内内部 \\
\hline 0.3 & 0.3 & 0.1 \\
\hline 0.5 & 1.0 & 0.2 \\
\hline 0.7 & 2.4 & 0.4 \\
\hline
\end{tabular}

\begin{tabular}{|c|c|c|}
\hline \multirow[t]{2}{*}{$\mathrm{W} / \mathrm{C}$} & \multicolumn{2}{|c|}{ 酸素透過量 $\left(10^{-10} \mathrm{~mol} / \mathrm{cm}^{2} \mathrm{sec}\right)$} \\
\hline & ひび割れ筒所 & 现外内部 \\
\hline 0.3 & 0.3 & 0.1 \\
\hline 0.5 & 3.5 & 1.3 \\
\hline 0.7 & 3.0 & 1.7 \\
\hline
\end{tabular}

れた。塩化物イオンはひび割れから鉄筋に沿って 部材内部に浸透する。したがって，ひび割れ近傍 にも，不動態皮膜の破壊を生じさせるに十分な量 の塩化物イオンが浸透し, 鉄筋はアノードと成り える.この時, 酸素透過量は健全なモルタル内部 の鉄筋と比較して，ひび割れと交わる部分の鉄筋 で多い，すなわち，多量の酸素が到達するひび割 れと交わる部分の鉄筋がマクロセルのカソードに 成りやすい，マクロセルは，アノードとカソード 間のモルタルによる電気抵抗が小さいほど, 形成 が容易である。したがって，ひび割れ近傍のモル タル内部の鉄筋がアノードとなるマクロセルが形 成したと考えられる.また，ミクロセルに関して は，次の通りである．塩化物イオンは，短期にお 


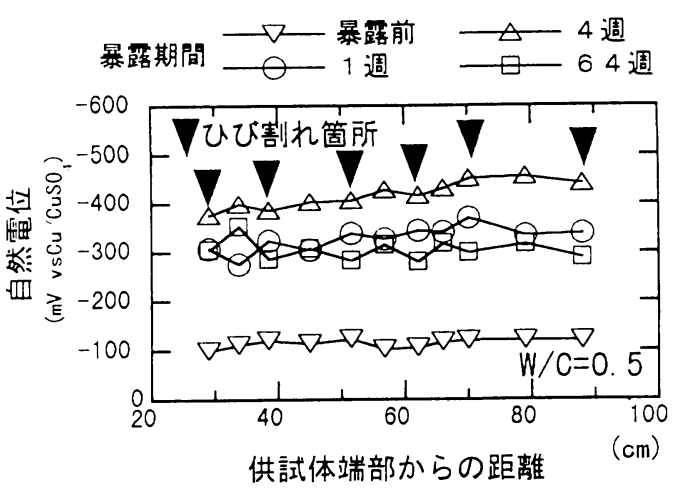

図-20 コンクリート供試体の自然電位の経時変化

いてすでに浸透したひび割れ箇所から，長期にな ると鉄筋内部に浸透する。 また，水セメント比が 70\%の場合は, モルタル中を通じて, 鉄筋表面に 浸透する塩化物イオン量も多い。その結果, 不動 態皮膜を破壊するに十分な量の塩化物イオンが到 達した鉄筋においては，ひび割れからの位置と関 係なく, 腐食の発生が確認された。この時, 水セ メント比が大きいほど, モルタル内部を透過する 酸素量が増加するため, 腐食速度も速い. 水セメ ント比が $30 \%$ の場合は，ひび割れと交わる部分の 鉄筋のみに塩化物イオンが浸透した。したがって， ひび割れ箇所で腐食が発生した。ただし，酸素透 過量はひび割れ箇所およびモルタル内部の鉄筋い ずれにおいても少ないため, 腐食速度は遅いと考 えられる。

\section{4.コンクリート供试体を用いた試跧}

モルタル供試体を用いた腐食促進試験により， ひび割れ部の物質透過性と腐食の関連性が, 明ら かとなった。ここでは, 鉄筋コンリート梁供試体 を用いた試験を行い，モルタル試験の結果を検証 する.

引張側主鉄筋の自然電位の経時変化を, 図-20 に示す.これによると, 暴露期間が 1 週では, ひ び割れと交わる鉄筋が，ひび割れ中間部のかぶり コンクリート中の鉄筋と比較して，早になること が認められる。一方, 暴露期間が64週では, ひび 割れ中間部のかぶりコンクリート中の鉄筋が，ひ び割れ箇所と比較して，卑になることが認められ る.したがって, 暴露期間が比較的短い場合は,

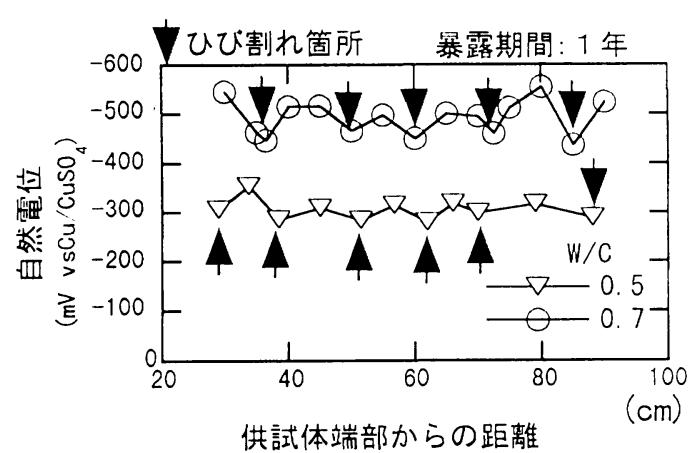

図-21 コンクリートの水セメント比か マクロセル腐食に及ぼす影響

ひび割れ籄所がアノードとなるマクロセルが形成 し，またミクロセル腐食もひび割れ箇所において 発生していたと考えられる.また, 暴露期間が長 期になると，ひび割れ箇所がカソード，ひび割れ 中間部のかぶりコンクリート内部の鉄筋がアノー ドとなると考えられる.

水セメント比が50\%および70\%における，自然 電位の測定結果を図-21に示す.これによると， 自然電位に関しては，水セメント比が70\%の場合 は，50\%の場合と比較して，卑になることが認め られる.したがって, 水セメント比が70\%の時が, $50 \%$ と比較して，腐食は促進していると考えられ る.

以上のことから，コンクリート供試体を用いた 試験においても，モルタル試験と同様の傾向であ ることが示された。すなわち, 腐食形成について は，暴露期間が長くなると，ひび割れと交差する 鉄筋のみならず，かぶりコンクリート内部の鉄筋 も腐食することが明らかとなった。このことから， 曲げひび割れ部にマクロセルが形成し，腐食が進 行すると, 鉄筋の断面減少が曲げひび割れの近傍 を含む部分（本研究の実験ではひび割れから約 $5 \mathrm{~cm}$ の範囲）で生じる可能性が慜念される.

\section{5. 結諞}

本研究では, 曲げひび割れを有する鉄筋コンク リート部材の腐食形成機構に関して, 水セメント 比に相違を設け，実験的に検討を行った。実験の 範囲内で，次のことが分かった。 
(1)曲げひび割れ部に形成する腐食形態は，経時的 に変化する，暴露期間が短期では，ひび割れと 交差する部分の鉄筋においてのみ, 腐食が発生 する.一方, 暴露期間が長期になると, 水セメ ント比が50\%あるいは70\%の場合，ひび割れ近 傍の鉄筋がアノードとなるマクロセルが形成し， 腐食が進行する。.また，水セメント比が70\%の 場合は，健全なかぶりコンクリート内部の鉄筋 においても，ミクロセル腐食は発生する。

(2)暴露期間によらず, 水セメント比が大きいほど, 腐食速度は速い.

(3)外部環境中の塩化物イオンは, 初め, ひび割れ を通じて，内部鉄筋に浸透する.内部鉄筋表面 に浸透した塩化物イオンは, その後, 鉄筋下面 に沿って, 健全なかぶりコンクリート内部へも 浸透する. その浸透量は, 水セメント比が大き いほど, 增加する。

(4)ひび割れと交差する部分の鉄筋への酸素透過量 は, 健全なかぶりコンクリート中の鉄筋への酸 素透過量と比較して, 多い.

以上の研究により，曲げひび割れ近傍に生じる 鉄筋とコンクリートの剥離部を考虑した，物質透 過性と腐食の関連性が明らかとなった。すなわち， 塩化物イオンは曲げひび割れを通じて, コンクリ 一ト内部の鋼材に容易に浸透する.したがって， 初めにひび割れと交差する部分の鉄筋において腐 食が発生する. その後, 暴露期間が経過すると, 塩化物イオンは鉄筋に沿って，ひび割れからかぶ りコンクリート内部へ浸透する。したがって，ひ び割れ近傍の鉄筋においても腐食が進行する.さ らに, 水セメント比が大きい場合は, かぶりコン クリート中を通じても, 塩化物イオンは鉄筋表面 に浸透する．この場合，ひび割れから離れた，健
全なかぶりコンクリート内部の鉄筋においても， 腐食が発生する。

\section{参考文献}

1 )蛭川友司, 見坊東光, 森芳徳, 伊藤洋: 海水が浸 透するひび割れ中の鉄筋腐食に関する基礎研究， 土木学会論文集, No.466/V - 19, pp.31 39, 1993.

2 ) 岡田清, 小柳治, 宮川豊章: コンクリート部材の ひびわれと鉄筋噟食に関する研究, 土木学会論文 報告集，第281号，pp.75〜87, 1979 .

3 )岡田清, 宮川豊章: コンクリートの水セメント比 およびひびわれが鉄筋腐食に与える影響について， セメント技術年報，No.33，pp.494 497，1979.

4 )大野義照, 鈴木計夫, 田村博 : コンクリート中の マクロセル腐食に及ほす各種要因の影響, セメン ト・コンクリート, No.601, pp.41 48, 1997.

5 )大即信明：ひび割れがコンクリート中の鉄筋の腐 食傾向に及ほす影䈏の電気化学的検討, セメント 技術年報，No.39，pp.288 291，1985.

6 )神山一：コンクリートのひび割れと鉄筋の腐食, セメント技術年報，pp.491 493，1972.

7 ）腐食防食協会：金属の腐食・防食 Q \& A , 丸善株 式会社, pp.140 141，1988.

8 )水流徽, 前田龍, 春山志郎: 交流法腐食モ二タ一 の局部腐食への適用，防食技術 $28, \mathrm{pp} .638$ $644,1979$.

9 )木内芳夫, 宮川豊章, 岡田清 : コンクリートの電 気抵抗および酸素浸透について, 土木学会第38回 年次学術講演会概要集, 第 5 部, pp.265 266, 1983.

10)岡田清，小林和夫, 宮川豊章, 本田暂: 分極抵抗 法を用いた鉄筋腐食モニタリングによる補修基準 について, 第 5 回コンクリートエ学年次講演会講 演論文集, pp.249 252, 1983.

11)大即信明, 横井聡之, 下沢浩：モル夕ル中鉄筋の 不㑬態に及ほす塩素の影聙, 土木学会論文集, 第 360 号 / V -5, pp.111 118, 1985.

12)枅田佳寛, 友沢史紀, 安田正雪, 原謙治: コンク リート中への塩化物漫透速度に関する実験, コン クリート工学年次論文報告集 $10-2, \mathrm{pp} .493-498$ ， 1988.

(1997.11.27受付)

\title{
THE INFLUENCE OF W/C ON CORROSION MECHANISM NEAR BENDING CRACK
}

\author{
Nobuaki OTSUKI, Shinichi MIYAZATO, Tsunenori SHIBATA, \\ Makoto HISADA, Tarek Uddin Md. and Shigeyoshi NAGATAKI
}

\begin{abstract}
The influence of water to cement ratio on the corrosion mechanism of steel bars embedded near a bending crack was experimentally investigated. First, early corrosion tests were syudied using mortar. Chloride ion and oxygen permeations were investigated, considering the gap between steel and concrete. The influences of those permeations on macrocell corrosion were studied. Lastly, tests on concrete specimens were conducted to confirm the results obtained from the mortar cese. Results show that the permeation near the bending crack plays a important role in corrosion behavior.
\end{abstract}

